\title{
Water supply performance evaluation of the public service of drinking water Case study: East of Algeria
}

\author{
Khereddine BOUTEBBA ${ }^{1) A B C} \bowtie$, Ali BOUAMRANE ${ }^{2) E F}$, \\ Nawel GANAOUI ${ }^{3)}$ AB , Mohamed T. BOUZIANE ${ }^{4) ~}$
}

\footnotetext{
1) University of Mohammed Seddik Benyahia, Faculty of Sciences and Technology, Laboratory of Management, Maintenance and Rehabilitation of Facilities and Urban Infrastructure, Ouled Aissa, B.P. No. 98, 18000 Jijel, Algeria; e-mail: boutebba.khereddine@yahoo.fr

2) University of Kasdi Merbah-Ouargla, Laboratory of Management, Maintenance and Rehabilitation of Facilities and Urban Infrastructure, Algeria; e-mail: bouamrane.ali@univ-ouargla.dz

3) University of Souk Ahras, Faculty of Natural Sciences and Life, Algeria; e-mail: ganaoui.nawel@gmail.com

4) University of Mohamed Khider, Faculty of Sciences and Technology, Biskra, Algeria; e-mail: tbouziane@gmail.com
}

For citation: Boutebba K., Bouamrane A., Ganaoui N., Bouziane M.T. 2019. Water supply performance evaluation of the public service of drinking water. Case study: East of Algeria. Journal of Water and Land Development. No. 40 (I-III) p. 53-58. DOI: 10.2478 / jwld-2019-0005.

\begin{abstract}
This article presents the results of a survey using a questionnaire conducted in Algeria, to evaluate the quality of public drinking water service, and at the same time the level of dissatisfaction / satisfaction of the subscribers. A statistical analysis of the data has been conducted on a representative sample of general population to identify weaknesses and strengths related to the current state of water management. The assessment of the quality of service, and the quality of water, as well as the price of water under the influence of the geographical distribution of the population was also studied.

The results of the statistical analyses show a wide variability regarding the level of dissatisfaction/satisfaction of the subscribers. In order to simplify the interpretation, we gathered the results in the form of classes and groups in such way that the cities appear on GIS mapping software, with their inhabitants' degree of satisfaction.
\end{abstract}

Key words: correspondence factor analysis (CFA), GIS, performance evaluation, public service, survey

\section{INTRODUCTION}

The sustainable management of public drinking water service is a social issue, which is most commonly mentioned in the field of water management, and can be broadly defined as a planning process aimed at mobilizing water for social, environmental and economic development. This definition, which is very general and covers two requirements, the first one dealing with water itself: observation in quantity and quality of the resource, while the second one based on the operation of infrastructure. In this context, managers of public drinking water services are led to design and implement a strategy that takes into account a wide range of issues related to the concepts of sustainable management [HAIDER et al. 2016]. This makes the mis- sion entrusted very complex. On the one hand, there is the need to respond to development needs, and on the other hand, there is the issue of sustainability of infrastructure.

This has become a challenge, faced with managers' demands, who are therefore demanding the implementation of a strategy and a policy based on a plan related to the notions of sustainable management. Nowadays, numerous researches and studies have been developed to facilitate the tasks of managers. ENGELHARDT [2000], BLINDU [2004], HAIDAR [2006], NAFI [2006], MONFRONT [2007], and BOUKHARI et al. [2017] have introduced new management operations, but none of them can be considered as an universal study, as each of them reflects their own objectives and priorities, and therefore each has its advantages and disadvantages, among them, we mention three major ap- 
proaches namely; simple approach, sophisticated approach and mathematical method approach. The International Water Association (IWA), LEJARS and CANNEVA [2012] propose simple approaches for evaluating the performance of the public water service, which is carried out around a set of performance indicators covering the main aspects of the sustainable management of a service, organized in a panel with the advantage of being able to convince the top management of the service. Other authors carried out sophisticated approaches or complex approaches, in order to have a global vision of the performance or well-defined objective HUGUENIN [2013]. This is the case of the data envelopment analysis (DEA) method, which allows decisionmakers to indicate the margin of improvements that the organization has in relation to the efficiency score to interpret the obtained results. We can also mention the work of BENZERRA et al. [2012] who applied mathematical methods to put a prototype to evaluate the performance of sanitation systems.

In Algeria, despite the efforts made by the communities to develop the water sector in the last few years, however, the effectiveness of these efforts remains limited, because the current state of the management does not achieve the defined management objectives. The most notable of which are the absence of a continuous water distribution service, the defective state of the networks and the low endowment compared to international standards among others. Therefore, the main objective of this article is to propose a tool to evaluate the performance of the public drinking water service through a field survey, integrating a set of analytical tools to help the decision-maker to draw information designed to diagnose and assess the current state of management of the service rendered and to promote new strategies to address this deficiency.

For this, our research contribution will be addressed as follow:

- the first part of the study is to conduct a service level diagnostic, and to evaluate the performance of this process using a questionnaire submitted to subscribers and the management and operations department networks, as well as the collection of information available on the pulsed electroacoustic (PEA) system, etc.;

- the second step is an analytical process that based on the actions of the correspondence factor analysis (CFA) approach, in order to provide a powerful tool in the description of the links between the conclusions of the questionnaires sent to subscribers to facilitate interpretation tasks of previous results and questionnaires submitted to the network management and operation department;

- the last step will be devoted to a contribution leading to the mapping of the results.

\section{MATERIAL AND METHODS}

\section{DIAGNOSIS AND ANALYSIS OF THE CURRENT STATUS OF PUBLIC DRINKING WATER SERVICE}

In order to identify the existing insufficiency in the public drinking water service, we conducted a question- naire, intended to collect information from households, and from the service responsible for the management and operation of the public utility of potable water. It is comprised of three main sections, inspired by the works of BOISTARD [1993], CARTIER [2004], and ABDELBAKi [2014]. Including, a first section that touches the level of the given service. A second section that deals with information about water quality, as well as about the measures taken for improvement. Final section that specifies the inadequacies and the subscriber needs. A sample of 8567 subscribers' representative of the target population was interviewed in different locations of 14 provinces in the eastern Algeria. Each one lasted 5 minutes on average. The choice of sampling was made arbitrarily in a way that affects all categories of the population. This sampling provides sufficient information for the diagnosis where the draw is random, for the period of investigation, which extended from Thursday, 12.09.2013 to Saturday, 22.12.2014.

\section{RESULTS OF THE SURVEY NOTED BY SUBSCRIBERS}

We present the results of the survey noted by subscribers (Tab. 1).

Table 1. The results of the performance indicator survey

\begin{tabular}{|c|c|c|c|}
\hline Setting & Question & Response & Rate (\%) \\
\hline \multirow{5}{*}{$\begin{array}{l}\text { Appreciation of } \\
\text { the quality of } \\
\text { service }\end{array}$} & \multirow{3}{*}{$\begin{array}{l}\text { Your opinion on the state } \\
\text { of the distribution service? }\end{array}$} & good & 16.81 \\
\hline & & average & 33.19 \\
\hline & & bad & 50.00 \\
\hline & \multirow{2}{*}{$\begin{array}{l}\text { Does water cover your } \\
\text { needs? }\end{array}$} & yes & 75.44 \\
\hline & & no & 24.56 \\
\hline \multirow{11}{*}{$\begin{array}{l}\text { Appreciation of } \\
\text { water quality }\end{array}$} & \multirow{2}{*}{ Do you drink directly? } & yes & 44.87 \\
\hline & & no & 55.13 \\
\hline & \multirow{5}{*}{ What do you do? } & nothing & 44.87 \\
\hline & & boil & 0.22 \\
\hline & & chlorinate & 0.22 \\
\hline & & source water & 21.83 \\
\hline & & bottled water & 32.86 \\
\hline & \multirow{4}{*}{ Water quality } & acceptable & 45.63 \\
\hline & & turbidity & 26.75 \\
\hline & & bad taste & 18.45 \\
\hline & & bad smell & 9.17 \\
\hline \multirow{9}{*}{ Water price } & \multirow{2}{*}{$\begin{array}{l}\text { Do you know the price of } \\
\text { water? }\end{array}$} & yes & 7.31 \\
\hline & & no & 92.69 \\
\hline & \multirow{3}{*}{ The price of water is } & normal & 1.31 \\
\hline & & cheap & 98.69 \\
\hline & & very expensive & 0.00 \\
\hline & \multirow{4}{*}{ Pay more: What reason? } & maintenance & 8.41 \\
\hline & & quality & 61.24 \\
\hline & & pressure & 11.35 \\
\hline & & distribution & 19.00 \\
\hline
\end{tabular}

Source: own study.

\section{STATISTICAL ANALYSIS OF SURVEY RESULTS}

We applied a correspondence factor analysis (CFA) in order to find links between the subscribers, on the one hand, and the 3 studied parameters (appreciation of the quality of service, appreciation of the quality of water and the price of water), on the other hand. 
Then, we extended the application of the hierarchical ascending classification (HAC) technique to identify the set of the most possible homogeneous classes, and the most different possible from each other by their characteristics on a set of variables. This is the legend/key of thematic maps combining variables. For this purpose, we have associated a colour to each class. These colourings are reproduced in figures for the sake of cartography and for the observation of thematic classes produced during the previous stage.

\section{DESCRIPTIONS OF ANALYTICAL METHODS AND MATERIALS}

The data was processed by the multivariate analysis method, the correspondence factor analysis (CFA) using XLSTAT computer software package. This method is also very well complemented by tools of hierarchical ascending classification (HAC) or dendrogram, which allows to bring complementary visions, in particular by building classification trees of rows or columns.

\section{- Factorial correspondence analysis}

Based on the definition of CALOZ and COLLET [2011], collar CFA was developed during the decade 1970, mainly by Benzecri and his collaborators, the CFA constitutes an extension of the principal component analysis (PCA) (reserved for continuous variables) to nominal measurement scale variables. The objectives are: to compare, structure and hierarchize the information in order to identify the main relationships, to determine the significant factors, and to produce a synthesis, ultimately a model of the phenomenon. As for the PCA, graphic representation is an important support in the process of analysis and interpretation. Unlike the PCA, which processes all variables and spatial units simultaneously, the CFA compares two by two, either the rows or the columns. These rows and columns can be swapped without changing the results!

In spatial analysis, it offers the possibility of analysing and interpreting the structure of information according to two entries respectively, variables or spatial units. These variables and spatial units belong to the nominal scale; the contingency table usually contains the frequencies observed at the intersection of two entries. In such a table, rows and columns play an identical role, that is, the analysis attempts to explain the behaviour of the variables according to the objects or vice versa. In fact, there are two angles of observation and analysis of the same population. This property plays a fundamental role in the mathematical developments, and the procedures for calculating a CFA. By restricting itself to the space domain, the CFA finds applications for different themes related to territorial units, both internationally and nationally. All traditional areas are likely to be addressed, such as economy, water etc. The CFA is totally based on the concept of a contingency table defined as the PCA, lines are frequent but not necessarily attributed to space units; the columns are assigned to the variables. The dimensions of the table correspond to the number of rows $(\mathrm{N})$ and the number of columns $(\mathrm{M})$.

The notion of contingency requires that the sum of the elements of a line, like that of a column should have a meaning. From this condition, we deduce that the data must be of the same nature (we do not add numbers with reports!).

\section{- Hierarchical ascending classification}

The purpose of the HAC module is to obtain an automatic classification of set of individuals. It begins by determining among the $(n)$ individuals, the 2 individuals that are the most similar to the set of $(p)$ specified variables. It will then groups these 2 individuals to form a class. There is therefore at this level $(n-1)$ classes, a class formed of 2 individuals grouped viously, the other classes containing only one individual. The process continues by determining the 2 classes that are most similar and grouping them together. This operation is repeated until a single class gathers all the individuals [BOUBOU 2007]. This procedure is based on two choices:

- the determination of a criterion of resemblance between individuals; the method leaves the user the choice of the dissimilar;

- the determination of a dissimilar between classes: is a process called aggregation criterion; the method leaves the choice of this criterion to the user.

\section{RESULTS AND DISCUSSION}

\section{- Service quality assessment}

The results of the CFA and HAC conducted in this section are intended to assess the quality of drinking water service in the study area, where the results of the dendrogram of hierarchical ascending classification (Fig. 1). These

Symmetrical graph

(axes F1 and F2: 93.01\%)

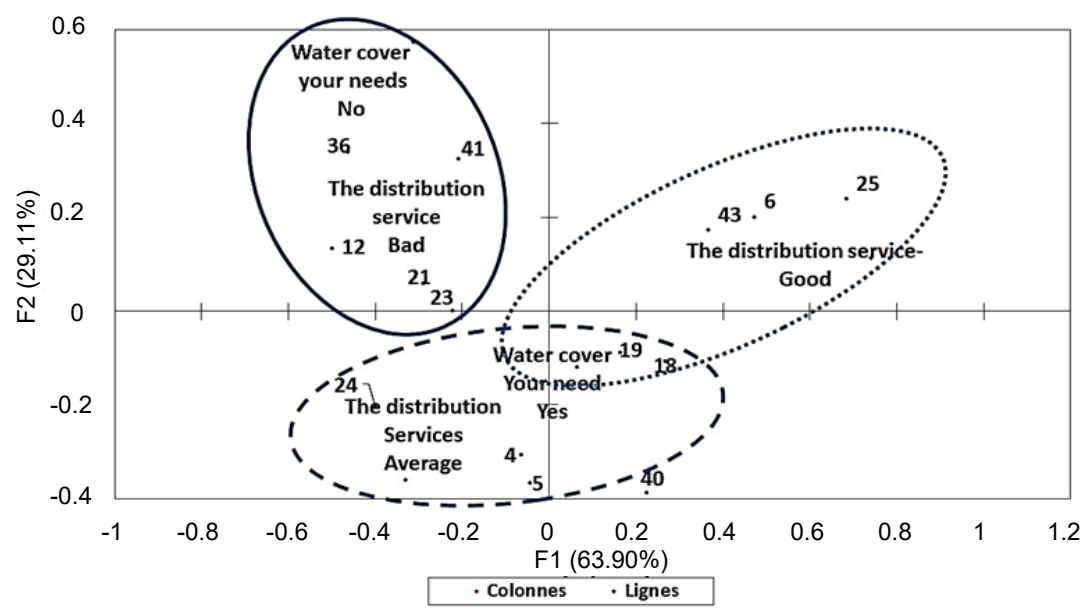

Fig. 1. Factor analysis of the correspondence carried out on the investigation of the quality of service; the eigenvalues of axes 1 and 2 are, respectively $63.90 \%$ and

$29.11 \%$; 4 = Oum el-Bouaghi, $5=$ Batna; $6=$ Béjaïa, $12=$ Tébessa, $18=\mathrm{Jijel}$,

$19=$ Sétif, $21=$ Skikda, $23=$ Annaba, $24=$ Guelma, $25=$ Constantine, $36=$ El Tarf, $40=$ Khenchela, $41=$ Souk Ahras, $43=$ Mila; source: own study 


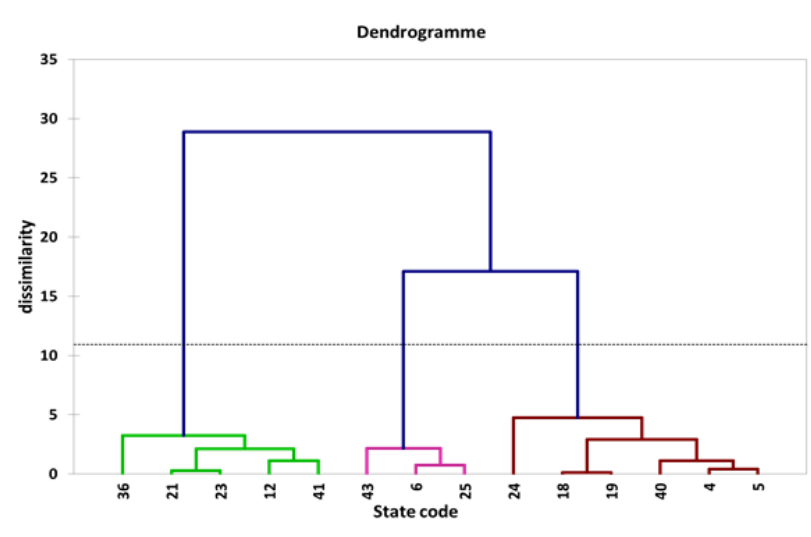

Fig. 2. Dendrogram showing the results of the assessment of service quality survey; source: own study

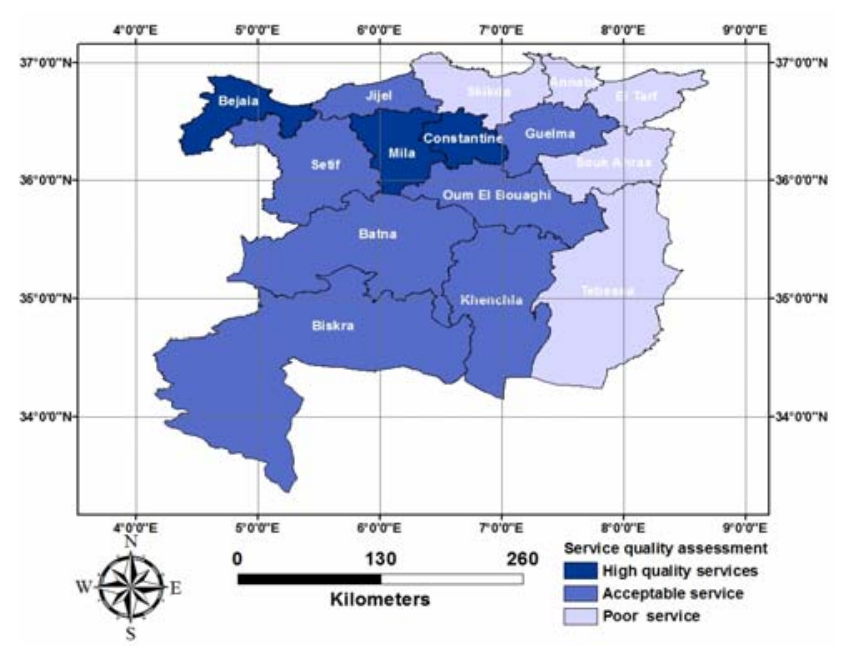

Fig. 3. Mapping of state classification results according to service quality assessment survey; source: own study

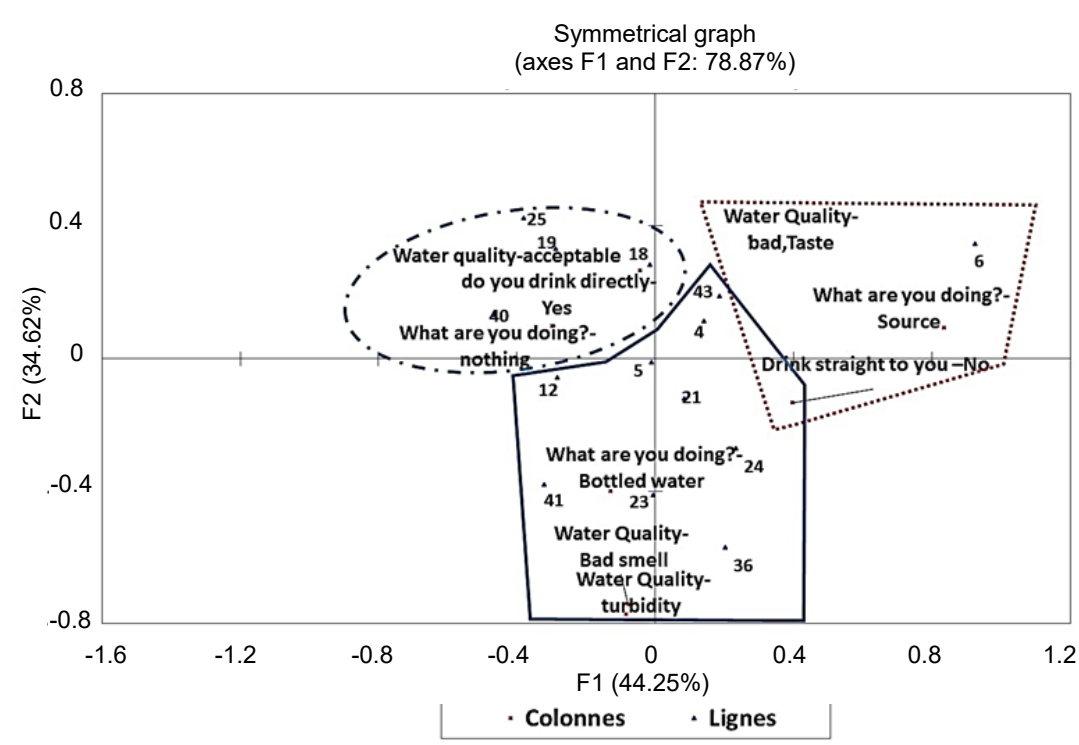

Fig. 4. The first two axes of the correspondence factor analysis (CFA) based on the results of the water quality assessment survey The eigenvalues of axes 1 and 2 are, respectively $44.25 \%$ and $34.62 \%$; $4=$ Oum el-Bouaghi, $5=$ Batna, $6=$ Béjaïa, $12=$ Tébessa, $18=\mathrm{Jijel}, 19=$ Sétif, $21=$ Skikda, $23=$ Annaba, $24=$ Guelma, $25=$ Constantine, $36=$ El Tarf, $40=$ Khenchela, $41=$ Souk Ahras, $43=$ Mila; source: own study surveys show that the provinces are divided into three main groups that can be found on the factorial plane of axes 1 and 2 of the CFA (Fig. 2).

According to the conclusions of this treatment (Fig. 3), we note that the provinces of group A (Constantine, Bejaia, Mila) provide a high-quality service, which means that the distribution service is good, and that the water covers all the needs of the population.

On the other hand, Group B (Annaba, Souk-Ahras, El-Tarf, Skikda, Tebessa) provides a poor distribution service, which results in a state that does not meet the needs of the population. Finally, with regard to the conclusions of group C (Batna, Oum El-Bougahi, Khenchela, Setif, Jijel, Guelma), these show that the respondents consider that the current situation of the service is acceptable and that the water covers their needs.

\section{- Water quality assessment}

The statistical analysis of the questionnaire data in this section highlights three main groupings (Fig. 4-6).

According to the results of group A, it was found that respondents from Bejaia province find that there is a deficiency in water quality. This forces a large number of subscribers not to consume this water directly, and to resort to the consumption of water sources and wells, which is often in bad taste.

However, at group B level, we find that most of the subscribers of Khenchela, Setif and Constantine provinces consume the water directly from the tap without specific treatment, which proves that the quality of the water is acceptable.

On the other hand, the results of the group $\mathrm{C}$ which gathers the province of Annaba, Skikda, Guelma, El-Tarf, Souk-Ahras, Tebessa, Jijel, Batna, Oum El Bouaghi and Mila indicate that subscribers only drink mineral water, or spring water because that of the tap is cloudy and tasteless, and therefore not drinkable.

\section{- Price of water and improvement of} the quality of the service

The results of the CFA conducted in this step (Fig. 7), show that most of the subscribers in each studied province ignore the price of water, but when they know it, the majority of them judge that the latter is not high. However, some people believe that access to water is a universal right and that it must be free; that is, water should not be bought or sold, while other subscribers agree that if no price is given to water, the population will continue to waste it. About paying more, the opinions of the subscribers of Tebessa, Khenchela, Setif, Constantine, Guelma, Oum El Bouaghi and Mila provinces were positive: they are ready to submit to this condition if the quality of the water is improved.

Regarding the regions where water does not cover the needs of the population, subscribers ask for the improvement of the distribution program (Fig. 4). 


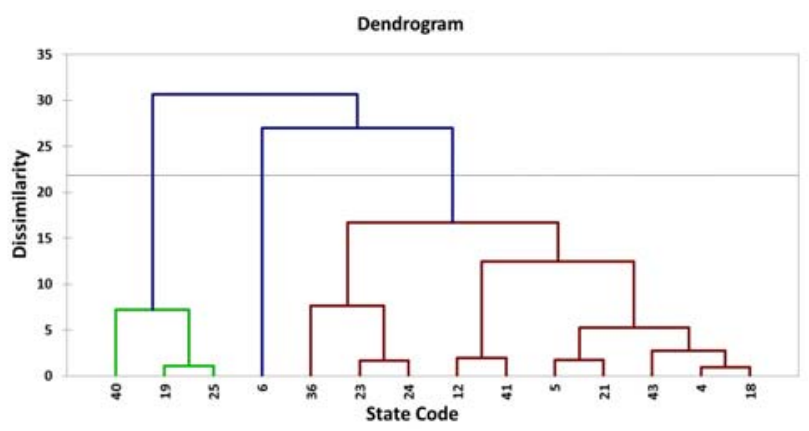

Fig. 5. Dendrogram showing the results of the water quality assessment survey; source: own study

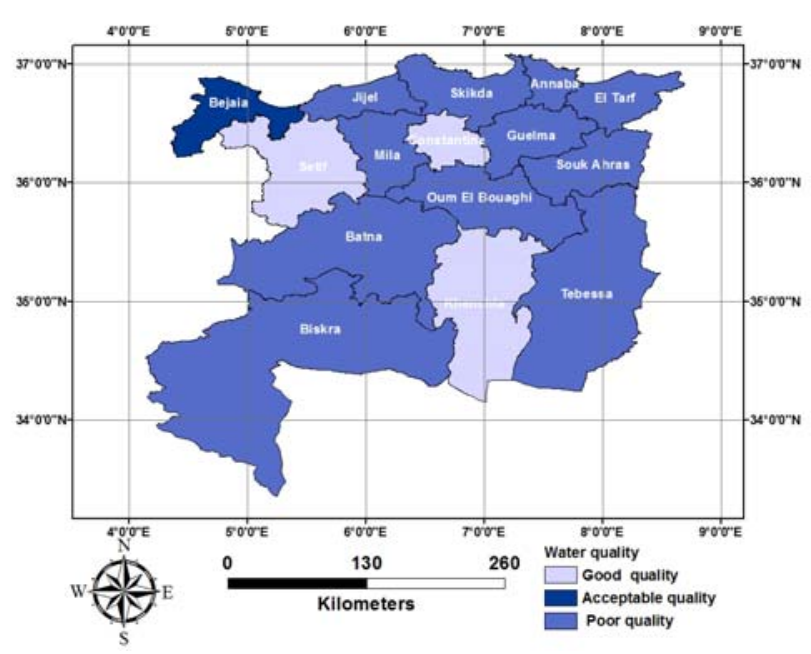

Fig. 6. Mapping of state classification results according to the water quality assessment survey; source: own study

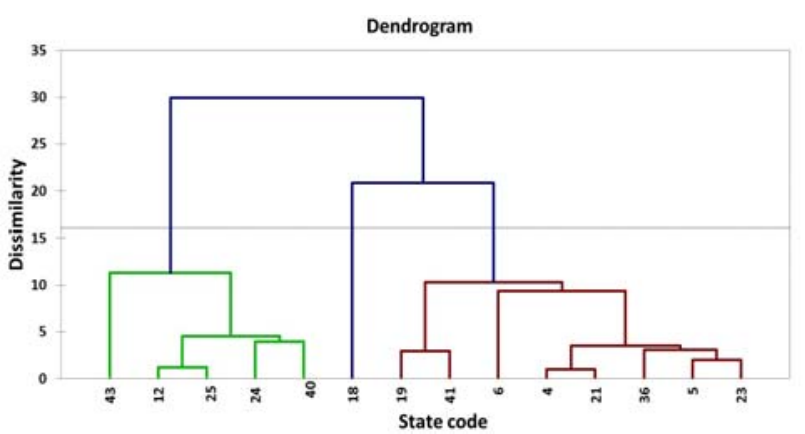

Fig. 8. Dendrogram showing the results of water price and quality of service improvement; source: own study

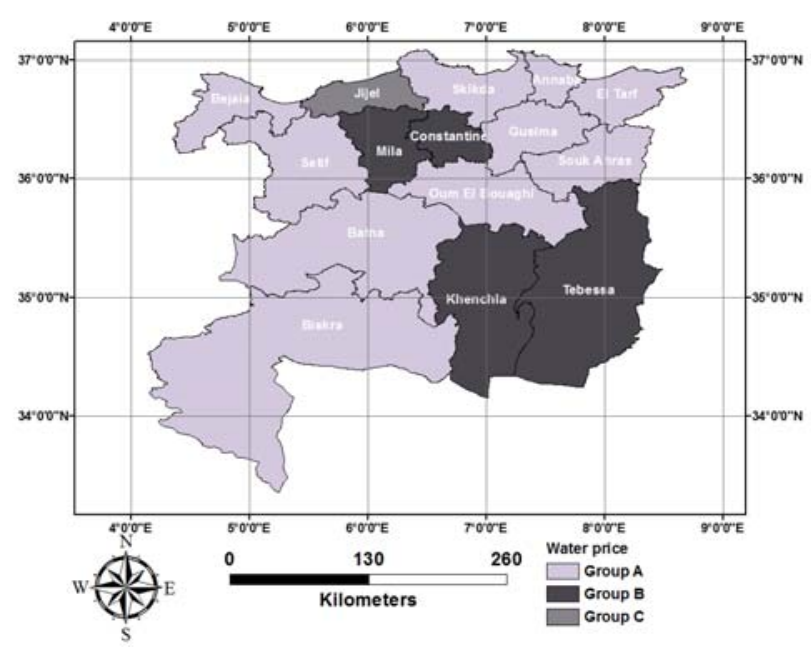

Fig. 9. Mapping of state classification results according to the results of water price and quality of service improvement; source: own study

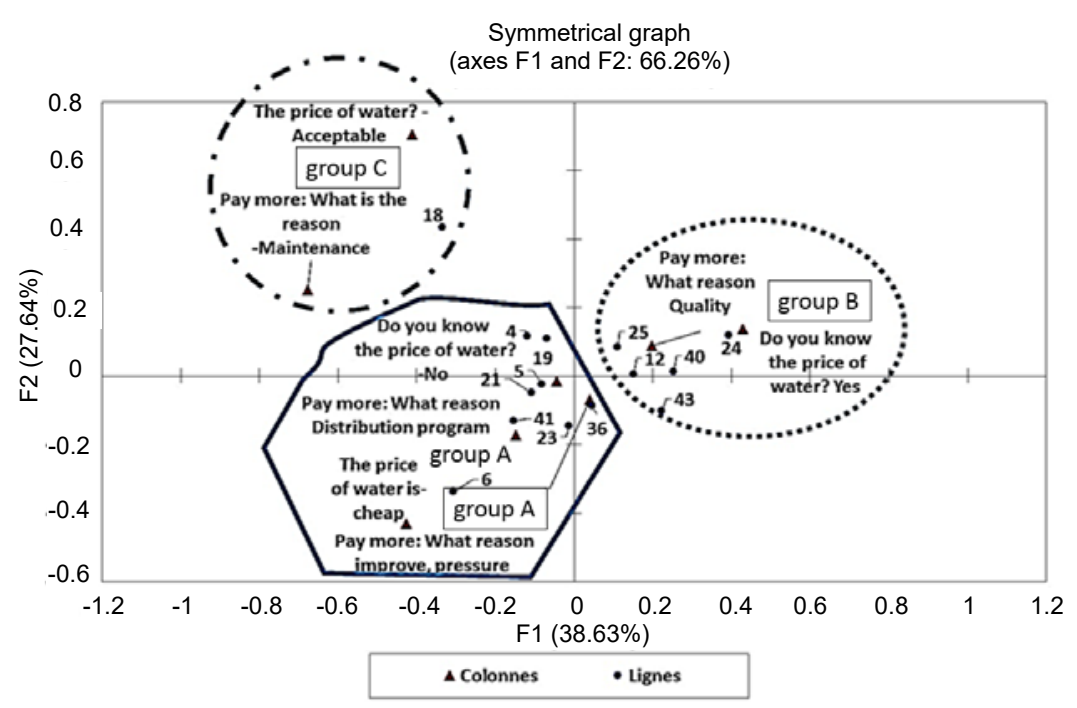

Fig. 7. Results of the Correspondence Factor Analysis (CFA) of the Water Price and Quality of Service Survey The eigenvalues of axes 1 and 2 are, respectively $38.63 \%$ and $27.64 \%$; $4=$ Oum el-Bouaghi, $5=$ Batna, $6=$ Béjaïa, $12=$ Tébessa, $18=$ Jijel, $19=$ Sétif, $21=$ Skikda, $23=$ Annaba, $24=$ Guelma, $25=$ Constantine, $36=$ El-Tarf, $40=$ Khenchela, $41=$ Souk Ahras, $43=$ Mila; source: own study

\section{CONCLUSIONS}

In this study, our efforts are focused on the proposal of methodological decision support tools to diagnose and improve the performances of the public drinking water service according to an integrated management plan, through a field survey. As a starting point for the purpose of diagnosis and to identify the level of dissatisfaction/satisfaction of the service by the subscribers. To this end, we applied a statistical analysis on the obtained results to identify weaknesses and strengths related to the current state of management. Based on the findings of this treatment, a wide variability in level of performance is in the form of groups that allow us, among other things, to clearly identify the level of satisfaction/dissatisfaction of the provinces, thus enabling the manager to identify the priority action targets, in order to pay particular attention to each one of these provinces in developing development plans, but also to determine negligible elements to lighten the study. To simplify the interpretation, we have displayed the analy- 
sis results as classes so that the provinces appear on the GIS mapping software with a grade reflecting their priority. Finally, the work we have developed in this study is considered as the culmination of several works, dealing with the question of improving the mode of management of the public water service. It would be very interesting to continue the development of this work, to introduce another extension for the evaluation of public service management performance based on multicriteria analysis techniques, in order to identify the priority actions for improvement thanks to the indicators of performance that are sensitive to the efficiency of management.

\section{REFERENCES}

ABDelbaki C. 2014. Modélisation d'un réseau d'AEP et contribution à sa gestion à l'aide d'un SIG-Cas du Groupement Urbain de Tlemcen [Modeling of a potable water supply network and contribution to its management using a GIS-Case of the Tlemcen Urban Group]. PhD thesis. Tlemcen, Algeria. University Abou Bakr Belkaid pp. 208.

Benzerra A., Cherrared M., Chocat B., Cherquiac F., ZekiOUKD T. 2012. Decision support for sustainable urban drainage system management: A case study of Jijel, Algeria. Journal of Environmental Management. Vol. 101 p. 46-53.

BLINDU I. 2004. Outil d'aide au diagnostic du réseau d'eau potable pour la ville de Chisinau par analyse spatiale et temporelle des dysfonctionnements hydrauliques [Tool for the diagnosis of drinking water network for the city of Chisinau by spatial and temporal analysis of hydraulic malfunctions]. $\mathrm{PhD}$ Thesis. Saint-Etienne, France. National School of Mines pp. 263.

BoISTARD P. 1993. Qualité et prix des services publics de distribution d'eau potable. Approche d'un prix de la qualité de l'eau et de la desserte. Economies et finances [Quality and price of public water supply services. Approach to a price for water quality and service]. PhD Thesis. Paris. Ecole Nationale des Ponts et Chaussées pp. 448.

Boubou M. 2007. Contribution aux méthodes de classification non supervisée via des approches pré topologiques et d'agrégation d'opinions [Contribution to unsupervised classification methods via pre topological and opinion ion aggregation approaches]. PhD Thesis. Université Claude Bernard-Lyon I pp. 190.

Boukhari S., DjebBar Y., Amarchi H., Sohani A. 2017. Application of the analytic hierarchy process to sustainability of water supply and sanitation services: the case of Algeria. Water Science and Technology: Water Supply. Vol. 18. No. 4 p. 1282-1293.

Caloz R., Collet C. 2011. Analyse spatiale de l'information géographique [Spatial analysis of geographic information. PPUR Presses polytechniques]. Lausanne. PPUR Presses polytechniques. ISBN 978-2-88074-902-6 pp. 383.

CARTIER J.-F. 2004. Enquête sur la consommation d'eau et la contamination environnementale à Saint-Augustin, Basse-Côte-Nord Baie-Comeau [Survey of Water Consumption and Environmental Contamination in Saint-Augustin, Lower North Shore. Baie-Comeau]. Agence de développement de réseau local de services de santé et de services sociaux de la Côte-Nord pp. 19.

ENGELHARDT H.T. 2000. The foundations of Christian bioethics. Taylor and Francis. ISBN 902651557X pp. 440.

HAIDAR H. 2006. Réhabilitation des réseaux d'eau potable: méthodologie d'analyse multicritère des patrimoines et des programmes de réhabilitation [Rehabilitation of drinking water networks : methodology for multi-criterion analysis of heritage and rehabilitation programs]. PhD Thesis. Lyon. L'Institut National des Sciences Appliquées pp. 227.

Haider H., SAdiQ R., TeSFAmariam S. 2016. Intra-utility performance management model (In-UPM) for the sustainability of small to medium sized water utilities: Conceptualization to development. Journal of Cleaner Production. Vol. 133 p. 777-794.

HuguenIN J. 2013. Data Envelopment Analysis (DEA). Un guide pédagogique à l'intention des décideurs dans le secteur public [Data Envelopment Analysis (DEA). A curriculum guide for policy makers in the public sector. IDHEAP]. Lausanne. IDHEAP. ISBN 978-2-940390-56-4 pp. 88.

Lejars C., Canneva G. 2012. Durabilité des services d'eau et d'assainissement [Sustainability of water and sanitation services] [online]. [Access 20.03.2018]. Available at: https:// eau3e.hypotheses.org/files/2009/10/presentation_etude_ durabilite gignac.pdf

MONFRONT L. 2007. Réseaux d'assainissement, gestion patrimoine et tuyaux en béton [Sanitation network, heritage management and concrete pipes]. The editions of CERIB. Vol. 108. ISSN 0249-6224 pp. 72.

NAFI A. 2006. La programmation pluriannuelle du renouvellement des réseaux d'eau potable [The multi-year programming for the renewal of drinking water networks]. PhD Thesis. Strasbourg. University of Louis Pasteur, UMR CemagrefEngees en GSP, Strasbourg I, France pp. 232.

\section{Khereddine BOUTEBBA, Ali BOUAMrane, Nawel GANAOUI, Mohamed Tewfik BOUZIANE}

\section{Ocena działania publicznych służb zaopatrzenia w wodę pitną - przykład wschodniej Algierii}

\section{STRESZCZENIE}

W artykule przedstawiono wyniki ankiety przeprowadzonej w Algierii metodą kwestionariuszy celem oceny jakości usług publicznego zaopatrzenia w wodę, a tym samym satysfakcji/niezadowolenia ankietowanych. Statystyczną analizę danych przeprowadzono na reprezentatywnej próbie generalnej populacji, aby określić mocne i słabe strony bieżącego stanu gospodarki wodnej. Przeprowadzono także ocenę jakości usług, jakości wody i ceny wody w odniesieniu do geograficznego rozmieszczenia ludności.

Wyniki analiz statystycznych wskazują na duże zróżnicowanie poziomu satysfakcji/niezadowolenia ankietowanych. Aby uprościć interpretację, zebrano wyniki w postaci grup i klas w taki sposób, że miasta pojawiają się w graficznym programie GIS wraz z poziomem satysfakcji ich mieszkańców.

Słowa kluczowe: ankieta, czynnikowa analiza korespondencji (CFA), GIS, ocena działania, usługi publiczne 